\title{
Investigation of the Effects of Distance from River and Peat Depth on Tropical Wetland Forest Communities
}

\author{
Edi Mirmanto $^{1)}$, Shiro TsuYuZaki ${ }^{2}$, Takashi Kohyama $^{2)}$ \\ ${ }^{1)}$ Research Centre for Biology-LIPI, Juanda 22, Bogor, Indonesia. Tel: +62-251-322035 \\ ${ }^{2}$ Graduate School of Environmental Earth Science, Hokkaido University, Sapporo 060-0810 Japan \\ Tel: +81 117064497 FAX: +81 117064954
}

\begin{abstract}
A plot census for trees over $5 \mathrm{~cm}$ in diameter at breast height was conducted in tropical wetlands to understand the effects of distance from river and peat depth on the development of communities, using $1450 \mathrm{~m}$ $50 \mathrm{~m}$ plots in Central Kalimantan, Indonesia. There are 294 taxa of woody species were recorded. Combretocarpus rotundatus, Palaquium leiocarpum, Stemonurus scorpioides and Tristania whittiana are the common species. In the 14 plots, Stem density and cumulative basal diameter ranged from 1612-3088/ha, and 18.5-44.6 $\mathrm{m}^{2} /$ ha, respectively. Species richness $(S)$ ranged from 41 to 87 . Diversity index $\left(H^{\prime}\right)$ and evenness $\left(J^{\prime}\right)$ varied from 1.29 to 1.68 and 0.771 to 0.910 , respectively. Stem density was positively related to distance from river but not to peat depth. Geographical differences were also related to the stem density. $H^{\prime}$ was related to distance from river, but $S$ and $J$ ' were not explained by any environmental factors examined. Plot distribution patterns were examined by detrended canonical correspondence analysis (DCCA). DCCA ordination indicated that distance from river, and hence the intensity and/or frequency of flooding more adequately explained plant community distribution patterns than peat depth. Geographical differences also significantly affected the distribution patterns. Therefore, the distance from river is a suitable parameter to use to investigate plant community distribution in tropical wetland forests, even if peat thickness differs greatly.
\end{abstract}

Key words: Central Kalimantan, detrended canonical correspondence analysis (DCCA), distance from river, Indonesia, peat depth, species diversity

\section{INTRODUCTION}

Asian tropical wetland forests, represented by peat swamp and heath (kerangas) forests, are distributed in Sumatra, Kalimantan and Irian Jaya, and these two wetland forest types are widely established in Central Kalimantan, Indonesia (Anderson 1983; MacKinnon et al. 1996; Shepherd et al. 1997). Although these forest soils are characterized by poor nutritional conditions, they are unique and important ecosystems, because of their sensitivity to various disturbances, including human activities (MacKinnon et al. 1996; Page et al. 1999).

One objective of plant ecology is to detect relationships between a plant community and environmental factors. Plant community types in tropical wetland forests can often be distinguished from one another according to the distance from river (Brady 1997; Stoneman 1997; Shepherd et al. 1997; Page et al. 1999). This approach often assumes that flooding intensity and/or frequency are related to the distance from river to successfully examine this phenomenon. However, various other environmental variables, such as topographical, physical and chemical factors, are correlated to each 
other in wetlands of various regions (Tsuyuzaki et al. 1990; ter Braak \& Wiertz 1994; Keddy 2000), and plant community distribution patterns arranged by distance from river mask the effects of the other environmental factors on plant community development. In particular, peat depth is the prime determinant on plant community distribution patterns in various wetlands (Gore 1983; Keddy 2000). Therefore, an arrangement approach using a single factor was not applied in this study. To determine the key factors of plant community development, a multivariate analysis has been applied (Legendre \& Legendre 1998). We applied popular and recent multivariate analyses on tropical wetlands, where both distance from river and peat depth may affect plant community development.

The aims of this study are to investigate the spatial distribution pattern of plant communities in relation to distance from river and peat depth. To accomplish these objectives, ecological researches have established some permanent plots on some different habitats. This paper is a part of long-term, comprehensive study on peat-swamp and heath forests in Central Kalimantan.

\section{STUDY AREA AND METHODS}

The study on wetland forest communities was conducted on three locations in Central Kalimantan: Sebangau ( $2^{\circ} 18^{\prime} \mathrm{S}, 113^{\circ} 55^{\prime} \mathrm{E}, 10 \mathrm{~m}$ above sea level), Lahei ( $1^{\circ} 55^{\prime} \mathrm{S}, 114^{\circ} 10^{\prime} \mathrm{E}, 20 \mathrm{~m}$ a.s.l.) and Tanjung Puting ( $2^{\circ} 45^{\prime}$ S, $111^{\circ} 56^{\prime} \mathrm{E}, 10 \mathrm{~m}$ a.s.l.). Sebangau is about $20 \mathrm{~km}$ southwest of the city of Palangka Raya, the provincial capital of central Kalimantan. The Sebangau area has been disturbed by selective logging. Lahei is about $40 \mathrm{~km}$ northeast of Palangka Raya. The study site in Tanjung Puting is about 7 $\mathrm{km}$ far from Tanjung Harapan Village. In the three locations, a river is within $6 \mathrm{~km}$ of each plot.

The climate is type A (Schmidt \& Ferguson 1957) with a mean annual rainfall of about $2400 \mathrm{~mm}$. The mean daily temperature varied from $25^{\circ} \mathrm{C}$ to $33^{\circ} \mathrm{C}$ with high humidity (up to $90 \%$ ). The mean monthly rainfall is $>200 \mathrm{~mm}$ in most months, and the dry season usually begins in July and August. From the peat profile in Lahei, frequent flooding and drawdown during peat formation are suggested (Haraguchi et al. 2000).

Ten $50 \mathrm{~m} \times 50 \mathrm{~m}$ plots were established in the Sebangau area where human impact was relatively low. The plots were distributed along the trail from about $1 \mathrm{~km}$ from the river to the inland. The distance between plots was about 500-1000 $\mathrm{m}$, depending on the physiognomic change in vegetation. Three $50 \mathrm{~m} \times 50 \mathrm{~m}$ plots in Lahei were set up, in heath forests, two plots, and peat-swamp forest, one plot. The distance between the plots was about $1 \mathrm{~km}$. A $50 \mathrm{~m} \times 50 \mathrm{~m}$ plot was established in a peatswamp forest at Tanjung Putting. All research was conducted during 1993 and 2000.

In each plot, the taxa and girth of trees with $>15 \mathrm{~cm}$ in girth at $1.3 \mathrm{~m}$ (breast height) above the ground surface were recorded. Based on the girth, basal diameter of each tree was calculated. Voucher specimens were deposited in the Herbarium Bogoriense (BO), the Faculty of Science, Kagoshima University (KAGS) and GSEES, Hokkaido University. In each plot, the distance from the river was measured by a tape and GPS, and peat depth was recorded by a peat sampler in each plot.

Species richness $(S)$ was obtained by the plot records. Shannon ${ }^{\prime}$ s diversity $\left(H^{\prime}\right)$ and evenness $\left(J^{\prime}\right)$ were calculated in each plot to obtain the overall vegetation characteristics (Zar 1999). To counteract the effect of autocorrelation between the environmental factors, forward ridge regression analysis was used to estimate the determinants of the stem density, basal area, species richness, diversity and evenness with lambda adjusted to 1 (Zar 1999). The environmental variables (independent variables) 
investigated were distance from river, peat depth and latitude and longitude. Detrended canonical correspondence analysis (DCCA) was used to investigate the relationship between plots and environmental factors using CANOCO for Windows version 4.02 (ter Braak \& Samilauer 1998). DCCA analysis is generally a powerful tool which clarifies species-environment and plot-environment relationships, even with skewed species distributions, with samples taken from unusual sampling designs, and/or with highly intercorrelated environmental variables (Kent \& Coker 1992; Palmer 1993). Species with frequency $\geq 3$ were used for the analysis to eliminate effects of rare species (noise) on the ordination pattern. The four environmental factors used in the regression analysis were examined for DCCA. A Monte Carlo permutation test was used to confirm the statistical validity.

\section{RESULTS}

There were 8352 trees of 294 taxa belonging to 51 families in the 14 plots surveyed. Species richness $(S)$ in the plots ranged from 41 to 87 (Table 1). The lowest $H^{\prime}$ was obtained from the plot L2 which had the deepest peat and is $0.4 \mathrm{~km}$ far from the river. In this plots $J^{\prime}$ was also lowest. The highest $H^{\prime}$ and $J^{\prime}$ were 1.68 and 0.910 , respectively. Thirteen species were distributed in $\geq 10$ plots while $\geq 50$ species were recorded in a single plot. The most dominant family was Dipterocarpaceae, which occupied 12.6 $\%$ of the total basal area, and followed by Clusiaceae, Myrtaceae and Sapotaceae. Gymnacranthera eugeniifolia was present in all plots (Frequency, $F=14$ ), followed by Horfieldia crassifolia, Stemonurus scorpioides, Nephelium maingayi and Tristania whittiana $(F=12)$. From total basal area, Combretocarpus rotundatus was the most abundant species followed by Palaquium leiocarpum, Xanthophyllum eurynchum, Shorea balangeran and Eugenia densinervium. The mean tree density was $2689 \mathrm{ha}^{-1}$ (range 1612-3704) and the mean tree basal area was $31.5 \mathrm{~m}^{2} \mathrm{ha}^{-1}$ (18.5-45.4).

Table 1. Number of species, density, basal area and diversity of fourteen $50 \mathrm{~m} \_50 \mathrm{~m}$ plots in tropical wetland forests in Central Kalimantan. $\mathrm{L}=$ Lahei, $\mathrm{S}=$ Sebangau, $\mathrm{TP}=$ Tanjung Putting.

\begin{tabular}{|c|c|c|c|c|c|c|}
\hline $\begin{array}{l}\text { Plot code } \\
\left(\text { tree ha }^{-1}\right)\end{array}$ & $\begin{array}{l}\text { Density } \\
\left(\mathrm{m}^{2} \mathrm{ha}^{-1}\right)\end{array}$ & $\begin{array}{l}\text { Basal area } \\
\text { of species }\end{array}$ & $\begin{array}{c}\text { Number } \\
\left(H^{\prime}\right)\end{array}$ & $\begin{array}{c}\text { Diversity } \\
\left(J^{\prime}\right)\end{array}$ & $\begin{array}{c}\text { Evenness Distance } \\
\text { from river }(\mathrm{km})\end{array}$ & $\begin{array}{l}\text { Peat depth } \\
(\mathrm{m})\end{array}$ \\
\hline L1 2368 & 31.2 & 74 & 1.62 & 0.867 & 1.2 & 0.5 \\
\hline L2 1612 & 45.4 & 47 & 1.29 & 0.771 & 0.4 & 4.0 \\
\hline L4 2212 & 30.3 & 84 & 1.68 & 0.873 & 0.6 & 0.4 \\
\hline TP1660 & 44.6 & 87 & 1.64 & 0.846 & 2.0 & 0.8 \\
\hline S1 2160 & 26.5 & 80 & 1.68 & 0.883 & 2.5 & 2.5 \\
\hline S2 2892 & 27.9 & 74 & 1.66 & 0.888 & 3.3 & 3.0 \\
\hline S3 3116 & 31.0 & 79 & 1.58 & 0.833 & 3.8 & 3.0 \\
\hline S4 3700 & 34.8 & 76 & 1.50 & 0.798 & 4.4 & 3.5 \\
\hline S5 3704 & 34.3 & 67 & 1.47 & 0.805 & 4.8 & 4.5 \\
\hline S6 3088 & 34.8 & 68 & 1.59 & 0.868 & 5.7 & 4.0 \\
\hline S7 2956 & 20.7 & 70 & 1.53 & 0.829 & 2.1 & 2.0 \\
\hline S8 3072 & 29.4 & 67 & 1.62 & 0.887 & 1.6 & 1.5 \\
\hline S9 2304 & 30.9 & 48 & 1.53 & 0.910 & 1.5 & 1.5 \\
\hline S102800 & 18.5 & 41 & 1.39 & 0.862 & 1.2 & 1.5 \\
\hline
\end{tabular}


Of the 14 plots surveyed, distance from the river ranged from $0.4 \mathrm{~km}$ to $5.7 \mathrm{~km}$, and peat depth ranged from $0.4 \mathrm{~m}$ to $4.5 \mathrm{~m}$ (Table 1). In Lahei, the plots with deepest peat were located closest to river, i.e., $0.4 \mathrm{~km}$ from the river with a $4-\mathrm{m}$ peat depth. The depth became shallower, further from the river, i.e., $0.4 \mathrm{~m}$, at $0.6 \mathrm{~km}$ from river. However, in Sebangau, the peat depth increased with increasing distance from river. The plot in Tanjung Putting is located $2.0 \mathrm{~km}$ from river with a $0.8-\mathrm{m}$ peat depth.

Stem density was significantly explained by a multiple regression line using the three environmental factors: distance from river, latitude and longitude (Table 2), although the latitude and longitude were not significant. In total, therefore, stem density was positively related to distance from the river, but not to peat depth. $H^{\prime}$ was related to both distance from river and peat depth, but $S$ and $J$ ' were not explained by any regression modes. On the regression line, distance from the river showed a positive slope and peat depth showed a negative slope. This implies that $H^{\prime}$ increases with increasing distance and with decreasing peat depth. Also the results suggested that the species diversity is derived from mixed effects of the two environmental variables.

Table 2. Relationships between diversity and productivity parameters $(y)$ and distance from river $\left(x_{1}\right)$, peat depth $\left(x_{2}\right)$, latitude $\left(x_{3}\right)$, longitude $\left(x_{4}\right)$, evaluated by forward ridge regression analysis. Partial correlation coefficients are shown in parentheses. e: constant.

\begin{tabular}{|c|c|c|c|c|c|c|}
\hline$y=$ & $+a x_{1}$ & $+b x_{2}$ & $+c x_{3}$ & $+d x_{4}$ & $+e$ & $r^{2}$ \\
\hline Stem density $=$ & $\begin{array}{l}+226 x_{1}^{\mathrm{P}<0.05} \\
(+0.643)\end{array}$ & & $\begin{array}{l}+944 x_{3}^{\mathrm{NS}} \\
(+0.308)\end{array}$ & $\begin{array}{l}+643 x_{4}^{\mathrm{NS}} \\
(+0.500)\end{array}$ & -73291 & $0.502^{\mathrm{P}<0.05}$ \\
\hline Basal area $=$ & & $\begin{array}{l}+2.6 x_{2}^{\mathrm{NS}} \\
(+0.542)\end{array}$ & $\begin{array}{l}-22.8 x_{3}{ }^{\mathrm{NS}} \\
(-0.545)\end{array}$ & $\begin{array}{l}-13.7 x_{4}^{\mathrm{P}<0.05} \\
(-0.671)\end{array}$ & +1586.5 & $0.332^{\mathrm{NS}}$ \\
\hline Species richness $(S)=$ & & & & $\begin{array}{l}-8.02 x_{4}^{\mathrm{NS}} \\
(-0.338)\end{array}$ & +981.73 & $0.041^{\mathrm{NS}}$ \\
\hline Species diversity $\left(H^{\prime}\right)=$ & $\begin{array}{l}+0.042 x_{1}^{\mathrm{P}<0.05} \\
(+0.551)\end{array}$ & $\begin{array}{l}-0.066 x_{2}^{\mathrm{P}<0.05} \\
(-0.649)\end{array}$ & & & +1.604 & $0.327^{\mathrm{P}<0.05}$ \\
\hline Evenness $\left(J^{\prime}\right)=$ & $\begin{array}{l}+0.008 x_{1}^{\mathrm{NS}} \\
(+0.304)\end{array}$ & $\begin{array}{l}-0.020 x_{2}^{\mathrm{P}<0.05} \\
(-0.578)\end{array}$ & & & +0.881 & $0.226^{\mathrm{NS}}$ \\
\hline
\end{tabular}

The first and second axes of DCCA ordination, respectively, explained $18.6 \%$ and $13.7 \%$ of the dispersion pattern of species data. Species-environment correlations on the first and second axes were 0.971 and 0.954 , respectively. A Monte Carlo permutation test confirmed that the test of all canonical axes was significant $(P<0.01)$. DCCA indicated that latitude was the primary determinant of the plant community establishment patterns in the present study (Fig .1). The distance from river, related to the first, axis was a more powerful variable in explaining plant community distribution patterns than peat depth, which was weakly related to the second axis. The pattern of DCCA changed little when species with $\geq 5$ frequency were used. Plot TP showed the highest score on the second axis and plots in Lahei were separated from plots in Sebangau, suggesting that the geographical factors remained even though species with $F>3-5$ were used. Plot L2 showed the highest score on axis one, even though this plot is close to the river. 


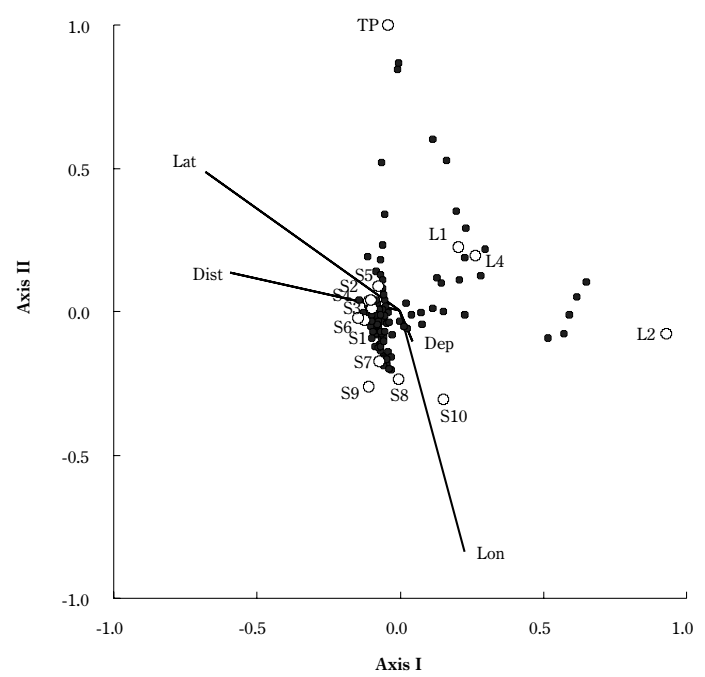

Fig. 1. DCCA ordination diagram on the first two axes. Open circles indicate plot scores and closed circles indicate species scores. For plot codes, see Table 1. Dst: distance from river, Dpt: peat depth, Lat: latitude, Long: longitude.

\section{DISCUSSION}

In the area studied, geographical factors as expressed by latitude and longitude, explained most of the plot scores on DCCA ordination, suggesting that geographical differences in species composition remained, even though the species frequency $>3(-5)$ was used for the analysis. These facts imply that geographical factors greatly determined plant community distribution patterns, even when the distance between the locations is less than a few hundred kilometers. While, on an smaller scale, the characteristics of plot L2 in Lahei were different from those of the other Lahei plots. This suggests that the local and/or edaphic factors are also important in determining the plant community distribution patterns.

Of the two local factors, distance from river and peat depth, distance from river seemed to more adequately explain the plot distribution scores of the ordination. Flooding frequency and intensity are determinants of riverside communities (Keddy 2000), and generally decrease with increasing distance from river. Flooding has both advantages and disadvantages to plant establishments. The advantage is that riverside plant communities often receive more nutrients from river flow than inland communities (Oliver \& Larson 1990), and the availability of nutrients and efficiency in nutrient cycling influence forest community distribution patterns (Page et al. 1999). If this is true, the basal area and/or stem density are expected to be higher closer to the riverside. However, in this study stem density in the plots closer to the river was lower, and basal area did not differ between plots. It was indicated that the stem size actually became smaller in plots closer to the river. Therefore, the positive effects of nutrient accumulation on plant growth seemed to be less near the riverside, or were outweighed by the advantages. The disadvantages of flooding are mainly inundation and physical disturbance. Flooding 
decreases primary productivity, because physiological and physical mechanisms in plant tissues do not function properly under high water stress (Tang \& Kozlowski 1982; Save \& Serrano 1986; Hurng et al. 1994; Ismail \& Noor 1996). The presence of flood-tolerant species results in a difference in species composition from riverside to the inland (Oliver \& Larson 1990). As a result, water-logging duration stimulates habitat segregation (Robertson et al. 1978; Inoue \& Nakagoshi 2000).

In heath forests, peat depth has a more important role in determining the distribution of species than does microtopography (Miyamoto et al. in press). However, peat depth is generally shallower in heath forests than in peat swamp forests. The thickness of surface peat affects tree establishment pattern, but the effect of thick peat on tree establishment may become homogenous when peat depth is longer than root depth. Topography, i.e., elevational difference, plays a relatively small role on the construction of forest communities, but topographical complexity increases species richness (Graniero \& Price 1999). Studies in a mixed-dipterocarp forest (Baillie et al. 1987) and a neotropical lowland forest (Becker et al. 1988) stated that microtopograhical variation has an effect on water availability and the aeration status of soil.

While no significant correlations between distance to river and $S$ were found in this study, $H^{\prime}$ was lower in the plots closer to river and/or with deeper peat. Flooding reduces species richness in riverside floodplain forests (Hupp 1992), while no significant reduction of species richness was observed in the present study. Our study suggested that species diversity $\left(H^{\prime}\right)$ was determined by local factors, distance from river and peat depth, rather than geographical differences. Further studies are required to confirm local-scale relationships between species diversity and environmental factors, including hydrological informatoin.

ACKNOWLEDGMENTS This work was financed by Research Center for Biology under LIPIJSPS Core University Program on Environmental Management of Wetland Ecosystems in Southeast Asia. We wish to thank Suwido H. Limin, Patih, Agung and Adi of Palangka Raya University, Dirman, Wardi and Aden Muhidin of Herbarium Bogoriense and anonymous reviewers for their tremendous help.

\section{REFERENCES}

Anderson, J.A.R. 1983. The tropical peat swamps of Western Malesia. In: A.J.P. Gore (ed.) Ecosystem of the World, 4B,Mires: Swamp, Bog, Fen and Moor. Elsevier, Amsterdam. pp. 181-199

Baillie, I.C., Ashton, P.S, Court, M.N., Anderson, J.A.R., Fitzpatrick E.J. \& Tinsley, J. 1987. Site characteristics and the distribution of tree species in Mixed Dipterocarp Forest on tertiary sediment in Central Sarawak, Malaysia. Journal of Tropical Ecology 3: 201-220.

Becker, P. \& Rabenold, P.E. 1988. Water potential gradient for gaps and slope in a Panamanian tropical moist forest dry season. Journal of Tropical Ecology 4: 173-184.

Brady, M. 1997. Effects of vegetation changes on organic matter dynamics in three coastal peat deposit in Sumatra, Indonesia. In: In: J.O. Rieley \& S.E. Page (eds.) Biodiversity and sustainability of tropical peatland. 113-134. Cardigan, UK: Samara Publishing.

Gore, A.J.P. 1983. Mires: swamp, bog, fen and moor. Ecosystems of the world 4A. Elsevier, 
Amsterdam.

Graniero, P.A. \& Price, J.S. 1999. The importance of topographic factors on the distribution of bog and heath in a Newfoundland blanket bog complex. Catena 36: 233-254.

Haraguchi, A., Shimada, S. \& Takahashi, H. 2000. Distribution of Peat and its Chemical Properties around Lahei in the Catchment of the Mangkutup River, Central Kalimantan. Tropics 10: 265-272.

Hurng, W.P., Lur, H.S., Liao, C.K. \& Kao, C.H. 1994. Role of abscisis acid, ethylene and polymines in flooding-promoted senescence of tobacco leaves. Journal of Plant Physiology 143: 102-105..

Hupp, C.R. 1992. Riparian vegetation recovery pattern following stream channelization: A geomorphic perspective. Ecology 73: 1209-1226.

Inoue, M. \& Nakagoshi, N. 2000. The effects of human impact on spatial structure of the riparian vegetation along the Ashida River, Japan. Landscape and Urban Panning 53: 111-121.

Ismail, M.R. \& Noor, K.M. 1996. Growth and physiological processes of young starfruit (Averhoa carambola L.) plants under soil flooding. Scientia Horticulturae 65: 229-238.

Keddy, PA. 2000. Wetland ecology: Principles and conservation. Cambridge University Press, Cambridge.

Kent, M. \& Coker, P. 1992. Vegetation description and analysis: A practical approach. CRC Press, Boca Raton, Louisiana.

Legendre P \& Legendre L. 1998. Numerical ecology (2nd edn.). Elsevier, Amsterdam.

MacKinnon, K., Hatta, G., Halim, H. \& Mangalik, A. 1996. The ecology of Kalimantan. Indonesian Borneo. Periplus Editions (HK) Ltd.

Miyamoto, K., E. Suzuki, T. Kohyama, T. Seino, E. Mirmanto and H. Simbolon In press. Habitat differentiation among tree species with small-scale variation of humus depth and topography in a tropical heath forest of Central Kalimantan, Indonesia. Journal of Tropical Ecology 19: 1-13.

Oliver, C.D. \& B.C. Larson. 1990. Forest stand dynamics. McGraw-Hill Inc., New York.

Page, S.E., Rieley, J.O, Shotyk, Ø.W. \& Weiss, D. 1999. Interdependence of peat and vegetation in a tropical peat swamp forest. Philosophical Transactions Royal Society of London, B 354: 1885-1897.

Palmer, M.W. 1993. Putting testing in even better order: The advantages of canonical correspondence analysis. Ecology 74: 2215-2230.

Robertson, P.A., Weaver, G.T. \& Cavanaugh, J.A. 1978. Vegetation and tree species patterns near the northern terminus of the southern floodplain forest. Ecological Monographs 48: 249-267.

Save, R. \& Serrano, L. 1986. Some physiological and growth responses to kiwi fruit (Actinidia chinensis) to flooding. Physiolgia Plantarum 5: 301-309.

Schmidt, F.R. \& Ferguson, J.A. 1957. Rain fall types based on wet and dry period ratios for Indonesia with New Guinea. Verhandelingen No. 42.

Shepherd, P.A., Rieley, J.O \& Page, S.E. 1997. The Relationship Between Forest Vegetation and Peat Characteristics in the Upper Catchment of Sungai Sebangau, Central Kalimantan. In: J.O. Rieley \& S.E. Page (eds.). Tropical Peatlands. Samara Publishing Limited, Cardigan. pp. 192-214.

Stoneman, R. 1997. Ecological studies in the Badas peat swamps, Brunei Darussalam. In: J.O. Rieley \& S.E. Page (eds.). Tropical Peatlands. Samara Publishing Limited, Cardigan. pp.221-230.

Tang, Z.C. \& Kozlowski, T.T. 1982. Some physiological and growth responses of Betula papyrifera seedling to flooding. Physilogia Plantarum 55: 415-420.

ter Braak C.J.F. \& Smilauer, P. 1998. CANOCO reference manual and user's guide to Canoco for Windows. Software for canonical community ordination (version 4). Centre for Biometry, 
Wageningen.

ter Braak, C.J.F. \& Wiertz, J. 1994. On the statistical analysis of vegetation change: a wetland affected by water extraction and soil acidification. Journal of Vegetation Science 5: 361-372.

Tsuyuzaki, S., Urano, S. \& Tujii, T. 1990. Vegetation of alpine marshland and its neighboring areas, northern part of Sichuan Province, China. Vegetatio 88: 79-86.

Zar, J.H. 1999. Biostatistical analysis (4th ed.). Prentice-Hall, Englewood Cliffs, NJ

Received Feb. 3, 2003

Accepted May 9,2003 